DIGITAL COMMONS
@ UNIVERSITY OF SOUTH FLORIDA

Volume 1

Issue 1 Volume 1 (2011): Women's Poetry

\section{ABO: Interactive Journal for Women in the Arts, 1640-1830}

2011

\title{
Revolutionary Imaginings in the 1790s: Charlotte Smith, Mary Robinson, Elizabeth Inchbald by Amy Garnai
}

Jennifer Golightly

University of Denver, jennifer.golightly@du.edu

Follow this and additional works at: https://digitalcommons.usf.edu/abo

Part of the Dramatic Literature, Criticism and Theory Commons, Educational Methods Commons, Feminist, Gender, and Sexuality Studies Commons, and the Literature in English, British Isles Commons

\section{Recommended Citation}

Golightly, Jennifer (2011) "Revolutionary Imaginings in the 1790s: Charlotte Smith, Mary Robinson, Elizabeth Inchbald by Amy Garnai," ABO: Interactive Journal for Women in the Arts, 1640-1830: Vol.1: Iss. 1 , Article 10. http://dx.doi.org/10.5038/2157-7129.1.1.9

Available at: https://digitalcommons.usf.edu/abo/vol1/iss1/10

This Reviews is brought to you for free and open access by Digital Commons @ University of South Florida. It has been accepted for inclusion in ABO: Interactive Journal for Women in the Arts, 1640-1830 by an authorized administrator of Digital Commons @ University of South Florida. For more information, please contact digitalcommons@usf.edu. 
Revolutionary Imaginings in the 1790s: Charlotte Smith, Mary Robinson, Elizabeth Inchbald by Amy Garnai

\section{Keywords}

1790s, Charlotte Smith, Elizabeth Inchbald, Mary Robinson

\section{Creative Commons License}

(c) (1) $\Theta$

This work is licensed under a Creative Commons Attribution-No Derivative Works 3.0 License. 
Amy Garnai. Revolutionary Imaginings in the 1790s: Charlotte Smith, Mary Robinson, Elizabeth Inchbald. New York: Palgrave Macmillan, 2009. \$80.00. ix + 242 pp. ISBN 978-0-230-57516-5.

Reviewed by Jennifer Golightly, Denver University

Amy Garnai's work focuses on three radical writers of the revolutionary decade in France: Charlotte Smith, Mary Robinson, and Elizabeth Inchbald. The primary argument of the work is not wholly unsurprising: Garnai asserts that through their novels, poems, plays, and essays, Smith, Robinson, and Inchbald contributed to the formation of a political discourse regarding social and political reform in the 1790s and that their efforts in this respect spanned the decade. That Garnai's analysis of these three writers runs across genres is still a relatively unique feature in studies of radical writing by women of the 1790s. Revolutionary Imaginings includes some important reflections on the traditional association of political writing with the novel, a fact that Garnai rightly identifies as creating a critical blind spot when it comes to the politics of plays and poems written by radical women writers.

Garnai's study examines Smith's long poem The Emigrants (1793) as well as four of her novels: Desmond (1792) and The Banished Man (1794), The Young Philosopher (1798), and Letters of a Solitary Wanderer (1800). She explores Robinson's early and often overlooked poem, Ainsi Va Le Monde (1790), and her political prose and poems that demonstrate sympathy for Marie Antoinette, including Impartial Reflections on the Present Situation of the Queen of France, "Marie Antoinette's Lamentation," and "Monody to the Memory of the Late Queen of France," as well as her sonnet sequence Sappho and Phaon, Hubert de Sevrac, and Walsingham, published in 1797, works that Garnai argues demonstrate the various aspects of Robinson's "radical positioning" in the latter half of the decade. Inchbald's two novels, A Simple Story (1791) Nature and Art (1796), as well as a fascinating examination of Inchbald's plays, which place the theater of the 1790s in the same political context as the novels of the period, complete the content of Garnai's analysis.

A primary problem in Garnai's study is her desire to demonstrate that contrary to critical opinion, Smith, Robinson, and Inchbald write works that evince revolutionary sympathies throughout the decade, not merely (in the case of Smith and Inchbald) during the first half of the decade, or, in Robinson's case, during the last. I am not convinced that this opinion is widespread in studies of the revolutionary decade. Garnai's basis for the commonality of this belief seems to be the remarks of E.P. Thompson in his landmark The Making of the English Working Class (1963), which, though an important study, is now more than forty years old. Although Garnai stipulates in her introduction that the problem she is responding to is primarily one evident in historical studies of the period and that literary studies are much more cognizant of the breadth of middle-class women's writing during the revolutionary decade, she provides no examples beyond Thompson's work and Albert Goodwin's The Friends of Liberty: The English Democratic Movement in the Age of the French Revolution (1979) as evidence of historiographies that "marginalize, if not erase women's participation in the debate" (2); subsequent references to such exclusionary historiography seem to be based primarily upon Thompson's work. 
A related and similarly problematic claim in Revolutionary Imaginings is that "middle-class, intellectual support of the French Revolution in Britain had begun to waver in 1792, and had virtually disappeared by mid-decade" (2). This claim, along with the one discussed above, provide the grounds for Garnai's isolation of Smith, Robinson, and Inchbald from other reformist writers of the 1790s. Like her previous claim, Garnai's assertion that British intellectual support for the revolution was diminished in 1792 and gone by the end of the decade is based primarily upon Thompson's book. The substantial body of recent research on Inchbald that presents her Nature and Art, published in 1796, as more radical than her A Simple Story, published in 1791, shows that critical understandings of the period have progressed since Thompson's work was published; though it references some of these more recent studies, Garnai's primary argument seems based to a large degree on older criticism such as Goodwin's and Thompson's.

Throughout Garnai's work, then, there seems to be a heavy reliance upon Thompson in particular as representative of a mode of thought about women's writing of the 1790s and its situation with respect to a public political debate during the period.

The value of Garnai's study is in her thought-provoking selection of texts by the writers she chose for this study as well as in the careful readings of these works by Smith, Robinson, and Inchbald. Not only did Garnai select texts that do not receive frequent critical attention, but her juxtaposition of these texts with others by the same writer- Smith's The Emigrants with The Banished Man and Letters of a Solitary Wanderer, Robinson's Ainsi Va Le Monde with her prose tracts on the death of Marie Antoinette, and Inchbald's A Simple Story and Nature and Art with her dramatic texts - highlights provocative patterns, themes, and modes of thought. For example, she provides important readings of Smith's lesser-known The Banished Man and Letters of a Solitary Wanderer, arguing against interpretations of the former as a work in which Smith renounces the revolutionary sympathy displayed in Desmond. Rather, Garnai points to indications of continuing support for the values that prompted the revolution and her dismay, certainly one shared by a number of so-called English Jacobins, over the bloody turn taken by that revolution and analyzes such indications. In conjunction with a nuanced reading of Smith's poem The Emigrants, often read as corroboration of a "volte face" on Smith's part, Garnai's analysis of The Banished Man lends support to her argument that Smith's radical sympathies were sustained over the course of the decade. The power of selections and readings such as these make Garnai's Revolutionary Imaginings an important read for students and scholars of women's writing of the 1790 s. 